\title{
New drugs in anaesthesia: can we afford them?
}

\section{Summary}

The most important challenge facing physicians today is the dilemma of providing high quality care in a fiscally responsible fashion. ${ }^{1}$ Cost can no longer be ignored. Pharmacoeconomics is a fundamental component of medical education. Economic issues should be an integral part of the drug development and clinical trials. ${ }^{2}$ While anaesthetists are concerned that the use of less expensive drugs may compromise patient outcome and satisfaction ${ }^{3}$ there is little evidence to support such concerns. ${ }^{4,5}$ This is a fertile area for intense future research.

Pharmacoeconomics is a dynamic. The cost of drugs is not static, patterns of drug use shift rapidly and clinical practice is in a state of constant change. The answer to cost containment is not simply to cut, cap, delist or merely hope for the best, but rather to manage and modify practice while accommodating changing needs. ${ }^{6}$

Educational programmes, guidelines, department policies, system changes and financial incentives can be implemented to ensure consistent and enduring adherence to the principles of pharmacoeconomics and value based care. Some suggest that national societies should create guidelines for cost-beneficial practice. Others favour physician autonomy in drug selection. ${ }^{3}$ Changing physician behaviour is difficult. This change will occur gradually and will be the topic of many emotionally charged philosophical debates. There will be great reluctance to deny patients pharmacologically superior drugs based on cost alone, especially since drugs are such a small portion of the total costs. ${ }^{7}$ We must exercise caution to ensure that we don't become penny wise and pound foolish. Drug acquisition costs are only one element in a large and complex equation. Concentrating on acquisition drug cost may be dangerous, even naive if we fall prey to knowing the cost of everything but the value of nothing. ${ }^{8}$

\section{Economic reality}

The status quo is simply unsustainable. The health care funding crisis has created the need to reform, restructure, reorganise, and downsize the entire sys- tem. Initially, costs were reduced by closing beds, now entire hospitals are closing. These changes are revolutionary in magnitude and are occurring at a frantic pace. In the next few decades the stress on the system will increase due to population demographics. The proportion of elderly will reach record numbers and the demand for health care will escalate.

The proliferation of new and expensive drugs in this fiscal environment demands that efforts are made to minimise inappropriately expensive prescribing patterns. The luxury of clinical decision making without considering cost is a paradise lost. ${ }^{9,10}$ It is no longer adequate to determine that a new drug is safe and effective. We must also determine the economic impact of a new drug, to establish costs, benefits and affordability. Physicians will be asked to participate, cooperate and compromise. Clinical choices must be justified while attempting to minimise cost and maximise quality.

\section{Knowledge about cost}

Knowledge of drug costs is an essential foundation for the discussion of pharmacoeconomics. Knowing the cost of the drug is equally important as knowing the pharmacokinetic and pharmacodynamic behaviour. Cost may be far more important than the modest circulatory response. ${ }^{11}$ It is disturbing that both physicians and patients know little about the cost of drugs and the cost of health care in general. ${ }^{4,12}$ Studies have shown that while $92 \%$ of anaesthetists agree that cost is important, only $42 \%$ know the cost of drugs they use everyday. Less than $1 \%$ of articles published report any data on cost. ${ }^{1}$ Most anaesthetists, $84 \%$, believe they were not adequately educated regarding cost and $53 \%$ believe that residents today still receive insufficient education. ${ }^{3}$

Posting drug costs and educational seminars can reduce the use of expensive drugs. $4,5,13$ In another study the use of price stickers had no effect on drug utilisation. ${ }^{14}$ While education alone may yield only temporary reductions in drug related expenditures, system changes, incentives, guidelines and rationing may be required to change physician practices and contain costs. . $^{3,4,15-17}$ 


\section{Drug acquisition costs}

Of all anaesthesia related costs, the cost of drugs is rising most rapidly. ${ }^{4}$ In 1991, the annual total world expenditure on currently available inhaled anaesthetics was $\$ 450$ million, (not including nitrous oxide). Since then, newer and more expensive agents, desflurane and sevoflurane, have been added. In general, new drugs are more expensive than old drugs. The difference is sometimes huge - orders of magnitude. Halothane is $3 \%$ the cost of desflurane. ${ }^{19}$

Drug prices are not static and they are not universal. Prices vary between countries, ${ }^{20}$ and may even vary between hospitals within the same city. Costs change due to volume discounts ${ }^{21}$ which are gaining popularity as large purchasing consortiums accept contracts for groups of hospitals. The cost of individual drugs may be difficult to calculate if price is dependent on bundling drug sales with other supplies and equipment.

Although small incremental costs have little impact on the cost for an individual patient, when these savings are multiplied by the millions of surgical procedures performed each year the cost is staggering. ${ }^{9,18}$ Substituting propofol for thiopentone results in an additional expenditure of approximately $\$ 7$ per patient. If $4 \%$ of patients in the United States (assuming 25,000,000 per year) receive propofol this would translate into a nationwide additional expenditure of $\$ 7,000,000$. If $50 \%$ of patients received propofol the additional expenditure would be $\$ 87,500,000$. At the end of the day we must determine whether the benefits justify the cost. A publicly funded system must allocate scarce resources for the greater good and must be convinced that additional expenditures will have a positive and palpable impact. Incremental costs must be covered by increasing tax dollars or transferring funds from other programmes or deficit funding.

However, drug costs must also be viewed in perspective and they represent a very small proportion of the total costs. Drugs account for only one third of the nonprofessional costs of anaesthesia. Anaesthetic agents represent between 4 to $25 \%$ of total hospital drug costs, $6 \%$ of operating room costs and $1 \%$ of total hospital costs. 3,4,22,23 The labour costs are orders of magnitude roughly 50 times greater than drug costs. While the drug costs for a one hour outpatient procedure varies from $\$ 11.05$ with isoflurane to $\$ 20.00$ with propofol operating room labour costs are approximately $\$ 680$ and PACU labour costs $\$ 328 .{ }^{24}$ Cost of propofol infusion for a long neurosurgical case is approximately half the price of a sugita clip $^{25}$ and represents a very small percentage of the total overall cost of care which amounts to approximately $\$ 25,000 .{ }^{26}$ The cost of anaesthetic drugs is minimal compared to the use of staples for wound closures. ${ }^{27}$ In cataract surgery the cost of anaesthetic drugs pales in comparison with the cost of Healonid and lens implants. ${ }^{28}$

\section{Cost $v s$ quality}

At one end of the spectrum some believe that drug costs are irrelevant and anaesthetic agents are cheap, even at twice the price. ${ }^{29}$ Despite the belief that cost is important the majority of anaesthetists agree that the best drug should be used regardless of cost. $4,22,27,28,30,31$ Even proponents of cost effectiveness research caution that the primary concern must be the well-being of the patient. $^{32}$

In contrast, others believe that low cost is more important than high quality. Even mediocre health care is better than no health care. While there is great reluctance to compromise the quality of care for cost savings, it is no longer possible to ignore the problem.? Anaesthetists are urged to examine the economic consequences of daily practice decisions, and ask "Why am I giving this drug? Is there a cheaper option?"33 The issue of credentialing physicians to track the use of expensive drugs has also been suggested. ${ }^{1}$ The era of physician autonomy is extinct: hospital administrators are demanding cost consciousness from physicians. Further cutbacks will not only increase pressure for cost-effectiveness and cost containment but also cost reduction and cost minimisation. The majority of anaesthetists agree that less expensive drugs could be used more frequently without decreasing the quality of care. ${ }^{3}$ For those who are not altruistically motivated, payment bundling for supplies, equipment, overhead and providers has caused a convergence of the interests of physicians and hospitals. ${ }^{15}$ The financial incentives of sharing cost savings has also been proposed. ${ }^{34}$

\section{Value based care}

Historically, the market for health care has not been governed by the conventional supply/demand and cost/quality equilibrium. The demand for health care has become price inelastic, choosing the best quality regardless of cost. ${ }^{34-37}$ The relationship between cost and outcome is complex but, in general, cost-benefit relationships have an upward although diminishing slope that will eventually plateau. Thereafter, investment of additional resources produces marginal or undetectable increments of improvement. ${ }^{34-38}$ Expensive drug choices must be justified by substantial rather than marginal improvements in patient care. Anaesthetic agents in use today have a proven record of safety and efficacy. The challenge for new and expensive anaesthetic drugs is that they must demonstrate a dramatic improvement over the already excellent drugs in our 
anaesthetic armamentarium. The conflict between cost and quality has necessitated the search for value based care, which defines the relationship between the costs of anaesthetic management strategies and the value of this care as reflected by patient outcome, consumer satisfaction and programme efficiency. ${ }^{33}$

Time is money. Operating room time has been estimated to cost between $\$ 2-6$ per min to $\$ 11.34 .{ }^{24}$ The demand for improved efficiency and quality outcomes has fuelled interest in new drugs with a rapid onset and short duration of action. Operating room efficiency may be improved using newer drugs with a short duration of action..$^{15}$ To evaluate the clinical benefits of new and faster drugs, studies have compared the time to open eyes, obey command, extubation and turnover times. ${ }^{40}$ Efficiency is multifactorial and drugs are not always the rate limiting step. ${ }^{33,41}$ Delays may be caused by nursing, housekeeping, physicians, ${ }^{42}$ and equipment related issues that cannot be improved by faster drugs.

PACU time has been estimated to cost approximately $\$ 1$ per minute ${ }^{7}$ or $\$ 103$ per patient ${ }^{22}$ and as much as $\$ 330$ per patient in the United States. ${ }^{24}$ New drugs could reduce PACU costs by reducing length of stay or allowing patients to bypass PACU altogether. Nursing salaries and wages represent $47 \%$ of the cost of an outpatient surgery centre. ${ }^{43}$ Staffing requirements are determined long before the patient arrives in PACU. Computerised models have documented theoretical PACU savings due to shorter length of stay and decreased nursing care requirements. ${ }^{43-46}$ Calculated cost savings assume that nursing care is funded on a piece meal fee for service basis. ${ }^{4-47}$ Real savings can only be achieved when there are fewer nurses assigned in advance to staff the PACU on a regular basis. This means job loss, layoffs and unemployment.

\section{Utilisation reviews}

Conflict arises when those who pay for the drugs are either unwilling or unable to pay. For financial reasons, hospitals may be forced to prohibit or discontinue some pharmaceuticals, to limit hospital formularies to the bare bones. ${ }^{1,48,49}$ The final goal of utilisation reviews is rationing. Rationing is already a reality in some hospitals and will become more common. . $^{53,33,50}$ Institutions have saved more than $\$ 400,000$ per year by tailoring the use of muscle relaxants, opioids, and inhalational agents. ${ }^{5,23,33,50}$ The majority of savings have been accomplished substituting older, cheaper, generic drugs such as pancuronium, halothane, morphine or fentanyl. Continuous education and reinforcement is required to maintain these changes. ${ }^{5}$ Many believe that outcome would not be affected using cheaper drugs ${ }^{33,51}$ and studies have not shown that perioperative outcomes are impaired. ${ }^{4}$ Dollars saved by the utilisation review process must be substantial since they must also subsidise the cost of the review process itself. Additional administrative staff is required to undertake these reviews. There is some concern that cost managers cost more than they contain.

\section{Guidelines}

Cost-effectiveness may become a criteria for acceptance of new drugs. ${ }^{52}$ This is somewhat disconcerting since guidelines for cost-effectiveness are controversial and arbitrary. ${ }^{53,54}$ The issues surrounding the use of guidelines are so complex that there are now guidelines for establishing guidelines. ${ }^{55}$ Laupacis has examined the conflict between cost and quality and defines four possible relationships. ${ }^{53}$ First, the scenario where a drug is cheaper and better resulting in universal acceptance. Second, the drug which is more expensive and associated with worse outcomes resulting in universal rejection. Third, the controversial but common scenario where the drug is better and more expensive. Arbitrary guidelines for acceptance are proposed (with the assumption that there is more money somewhere to pay the increased cost). The fourth scenario is also controversial and common, a drug which is cheaper but associated with less desirable outcomes. Laupacis suggests that if large costs savings can be achieved the trade off between cost and quality can be justified. ${ }^{53}$ Halothane is a good example of this controversy. Some anaesthetists use halothane as their drug of first choice because it is cheaper. ${ }^{56}$ Yet, other anaesthetists never use halothane..$^{51}$ They believe that halothane is of historical interest only, given the risk of hepatitis and the current medicolegal climate. ${ }^{57}$

\section{The pharmaceutical industry}

There is concern that the release and acceptance of newer agents may be far more important to the manufacturer than to our profession or our patients. ${ }^{31}$ A new muscle relaxant or inhalational agent may provide minimal improvements for the patient but provide millions in profit for the company. The pharmaceutical industry is the most common source of information regarding drug cost. ${ }^{51}$ Barriers to objective drug selection include, not only the sheer volume of information and hectic work schedules, but also the temptation to depend on commercial sources for continuing medical education. ${ }^{37}$ The influence of pharmaceutical company detailing, the "free lunch" and drug promotion through gift giving is an area of great concern. ${ }^{4}$ Some suggest that there is no such thing as a free lunch and we should choke on every bite of the tainted drug company donut. ${ }^{58}$ To address some of these issues the Canadian Medical Association 
has established guidelines for relationships between physicians and the pharmaceutical industry.

Others believe that we are buying more than just drugs and view relationships with the pharmaceutical industry as supportive and symbiotic. Over the years, new drugs developed by the industry have revolutionised the practice of medicine. The pharmaceutical industry sponsors a substantial amount of continuing medical education, contributes to scientific meetings, research awards, research grants, funds clinical trials and, through advertising, support research journals. We will continue to need the pharmaceutical industry to develop new drugs to meet current challenges and to finance our research efforts in clinical medicine and pharmacoeconomics. ${ }^{59}$

\section{Pharmacoeconomic studies}

For new drugs to replace existing drugs, it is no longer sufficient simply to demonstrate safety and efficacy in random, double-blind placebo-controlled trials, in the current health care environment they must meet higher standards. ${ }^{60,61} \mathrm{~A}$ new drug must offer a greater therapeutic benefit, and that benefit must be affordable. ${ }^{62}$ This has created a need for pharmacoeconomic studies.

There is a spectrum of opinion on pharmacoeconomics. At one end of the scale there is the belief that "pharmacoeconomics is bunk!" At the other end, there is the belief that pharmacoeconomic studies are the foundation for widespread policy decisions, clinical guidelines, formulary acceptance and insurance coverage.

If a consumer wants information on a new car, computer or television there are a variety of consumer report documents and magazines available. These evaluations are performed solely for the benefit of the buyer. The reports are compiled separate from the manufacturer and are funded by the consumer not the manufacturer. These publications do not accept advertising and if their results are used by manufacturers for marketing purposes they can be sued. In contrast, drug companies play a key role in developing and generating economic analysis used to advertise their drugs and to drive formulary decisions. There are warnings that policy decisions should not be based on economic studies furnished by drug companies that have spent millions on research and development and have tremendous vested interest in the study results. It can be difficult to determine if you are being educated by experts or manipulated by marketers. ${ }^{63}$

Pharmacoeconomics is not a rigorous science, and has been denounced as a "pseudoscience." Pharmacoeconomics is "rubbery" because it has a constantly shifting viewpoint which make the conclusions malleable depending on the perspective of the analysis.
Bias in technology assessment is a major problem but is inevitable since the economic validity of a new technology must be assessed from a some perspective. Physicians are sceptical and leery of being manipulated or misinformed by pharmaceutical companies and their paid representatives. ${ }^{64}$ For example, the most favourable calculation for the cost of desflurane has been reported by researchers with a vested financial interest in this drug. ${ }^{64}$ It has been said that, using low flow rates, desflurane is less expensive than isoflurane. The ultimate test is the use of the new drug in clinical practice. If desflurane is truly cheaper than isoflurane then anaesthesia drug budgets should decrease with increased desflurane use. ${ }^{19}$

In contrast, others believe that drug companies should play a fundamental role in pharmacoeconomic studies. They own the drugs and possess the most information about the products. Perhaps the most compelling reason for including the industry is that they have the financial resources required to fund these studies, especially today when research dollars are scarce. Since flaws in experimental design will eventually be revealed in the evaluation process and will adversely affect the credibility of the company. Therefore, it is in the company's best interest to ensure research is rigorous. Many companies commission studies at arms length precisely because they will be more credible when being considered by formulary purchasers. In some projects pharmaceutical firms relinquish control over the design, conduct, analysis, interpretation, reporting and publication. The only thing they do is sign the check. ${ }^{63}$ Some suggest that proposed studies should be reviewed by a health technology assessment council to ensure sound methodology and conforming to established and consistent guidelines and reduce bias. This would give the "Good Housekeeping" seal of approval to the study and improve credibility. Economic evaluation should be regarded as a technology which is promising, clearly helpful, yet still in need of refinement and like any new technology it can be wisely used or unintentionally abused. ${ }^{54}$ There will be increased pressure to link science and policy-making as a fundamental part of practising evidence based medicine. ${ }^{65}$ Cost-effectiveness analysis helps the policy-making process, but due caution is warranted about the limitations of the paradigm.

\section{Conclusion}

Cost containment and continuous quality improvement; can they coexist? New drugs may improve quality, but may also increase cost. This creates tension between quality improvement and cost containment. While drugs have played a fundamental role in shaping 
the health care system, research must now be committed to assess and identify the appropriate and affordable use of these new drugs. Value judgments are fundamental in the clinical decision-making process. ${ }^{10}$ The issues are economics and ethics. While cost should not be the overriding factor, we will be asked to employ the least expensive strategy for obtaining an acceptable outcome. The dilemma is the definition of "acceptable." How good is good enough? Quality at what cost? What can we afford? Unfortunately, given our shrinking budgets it is inevitable that some new technology will simply be unaffordable.

\section{References}

1 Tuman KJ, Ivankovich AD. High-cost, high-tech medicine: are we getting our money's worth? J Clin Anesth 1993; 5: 168-77.

2 Johnstone RE, Martinec $C L$. Anesthesia studies should include costs (Letter). Anesthesiology 1993; 79: 195-9.

3 Kantor GSA, Chung F. Anaesthesia drug cost, control and utilization in Canada. Can J Anaesth 1996; 43: 9-16.

4 Johnstone RE, Jozefczyk KG. Costs of anesthetic drugs: experiences with a cost education trial. Anesth Analg 1994; 78: 766-71.

5 Szocik JF, Learned DW. Impact of a cost containment program on the use of volatile anestherics and neuromuscular blocking drugs. J Clin Anesth 1994; 6: 378-82.

6 Milne $C$. You can't absorb the bumps if you are not flexible (Editorial). Canadian Healthcare Manager 1996; 3: 5.

7 Donati F. Cost-benefit analysis of neuromuscular blocking agents. Can J Anaesth 1994: 41: R3-R7.

8 Orkin FK. Meaningful cost reduction; penny wise, pound foolish. Anesthesiology 1995; 83: 1135-7.

9 Coben $N$. Reforming health care; efficient cost-effectve anesthesia. Journal $1995 ; 311$ :

10 Wetchler $B V$. Economic impact of anesthesia decision making: they pay the money, we make the choice. J Clin Anesth 1992; 4: 20S-4.

11 Rathmell JP, Brooker RF, Prielipp RC, Butterworth JF, Gravlee GP. Hemodynamic and pharmacodynamic comparison of doxicurium and pipecuronium with pancuronium during induction of cardiac anesthesia: does the benefit justify the cost? Anesth Analg 1993: 76: 513-9.

12 Jobnstone RE, Martinec $C L$. Costs of anesthesia. Anesth Analg 1993; 76: 840-8.

13 Becker KE, Carrithers J. Practical methods of cost containment in anesthesia and surgery. J Clin Anesth $1994 ; 6: 383-7$.

14 Horrow JC, Rosenberg $H$. Price stickers do not alter drug usage. Can J Anaesth 1994; 41: 1047-52.

15 Kapur PA. Pharmacy acquisition costs: responsible choices versus overutilization of costly pharmaceuticals. Anesth Analg 1994; 78: 617-8.
16 Kosecoff J, Kanouse DE, Rogers WH, et al. Effects of the National Institutes of Health consensus development program on physician practice. JAMA 1987; 258: 2708-13.

17 Schroeder SA, Myers LP, McPbee SL, et al. The failure of physician education as a cost containment strategy. JAMA $1984 ; 252$ : 225-30.

18 Lampotang $S$, Nyland $M E$, Gravenstein $N$. The cost of wasted anesthetic gases. Anesthesiology 1991; 71: S151.

19 Johnstone RE. Costs of inhaled anesthetics (Letter). Anesthesiology 1994; 80: 1404-5.

20 Cooper JO. The relative costs of anesthesia drugs in New Zealand versus the United States. Anesth Analg 1995; 80: 850 .

21 Palumbo FB, Schondelmeyer SW, Miller DW, Speedie SM. Battered bottom lines: the impact of eroding pharmaceutical discounts on health-care institutions. Am J Hosp Pharm 1992; 49: 1177-85.

22 Hudson RJl, Friesen RM. Health care "reform" and the cost of anaesthesia. (Editorial). Can J Anaesth 1993; 40: 1120-5.

23 Hawkes C, Miller D, Martineau R, Hull K, Hopkins $H$, Tierney $M$. Evaluation of cost minimization strategies of anaesthetic drugs in a tertiary care hospital. Can J Anaesth 1994; 41: 894-901.

24 Lubarsky DAS, GlassPSA. A comparison of maintenance drug costs of isoflurane, desflurane, sevoflurane and propofol with $\mathrm{OR}$ and PACU labor costs during a 60 minute outpatient procedure. Anesthesiology 1995; 83: Al035.

25 Aitken $H A$, Farling $P A$. The cost of propofol infusion in neurosurgery (Letter). Anaesthesia 1991: 46: 329.

26 Todd MMW, Sokoll DS, Maktabi MA, Hindman BJ, Scamman FL, Kirschner J. A prospective comparison of three anesthetics for elective supratentorial craniotomy. Anesthesiology 1994; 8: 1005-20.

27 Bevan DR. Anaesthesia pharmacoeconomics. Can J Anaesth 1993; 40: 693-5.

28 Scott PV. The costs of propofol in day surgery (Letter). Anaesthesia 1990; 45: 174-5.

29 Bailey $C R$, Tugger $R$, Cashman JN. Anaesthesia: cheap at twice the price? Anaesthesia 1993; 48: 906-9.

30 Rhodes SP, Ridley SP. Economic aspects of general anaesthesia. Pharmacoeconomics 1993; 3: 124-30.

31 Meyer RM. Costs of inhaled anesthetics: IV. Anesthesiology 1994; 80: 1406.

32 Detsky AS. A clinician's guide to cost-effectiveness analysis. Annals of Internal Medicine 1990; 113: 147-54.

33 Becker KE, Johnstone RE, Lubarsky DA. Choice of anesthetic drugs and muscle relaxants. American Society of Anesthesiologists Newsletter 1995; 59: 8-12.

34 Noel TA. The market has not failed! Anesth Analg 1993; 77: 1309-10. 
35 Martinec $C L$, Johnstone $R E$. In respones to "The market has not failed!" Anesth Analg 1993; 77: 1303.

36 Wessel $D$, Bogdanich $W$. Closed market-laws of economics don't often apply to health care field. Journal 1992; Al.

37 Hux JE, Naylor CD. Drug prices and third party payment. Do they influence medication selection? PharmacoEconomics 1995; 5: 343-50.

38 Grumbach $K$, BodenbeimerT. Painful vs. painless cost control. JAMA 1994; 272:

39 Laupacis A, Bourne R, Rorabeck C, et al. Costs of elective total hip arthroplasty during the first year. Cemented versus noncemented. J Arthroplasty 19'34; 9: 48 1-7.

40 Fisher $D M$. Surrogate end points - are they meaningful? Anesthesiology $1994 ; 81: 795-6$.

41 Patel N, Smith CE, Pinchak AC, Sidbu T, Podugu RR, Hagen JF. Desflurane is not associated with faster operating room exit times in outpatients. Clin J Anesth 1996; 8: 130-5.

42 Truong AT, Kleiman MJ,Bensimon SJ. Late operating room starts: experience with an educational trial. Can J Anaesth 1996; 43: 1233-6.

43 Marais $M L$, Maher $M W$, Wetchler $B V$. Reduced demands on recovery room resources with propofol compared to thiopental isoflurane. Anesthesiology Review 1989; 16: XXX.

44 Marais $M L$, Maher $M W$, Wetchler $B V$, et al. An adaptable computer model of the economic effects of alternative anesthetic regimens in outpatient surgery. Anesthesiology 1990; 73: A54.

45 Sung Y-F, Reiss N, Tillette T. The differential cost of anesthesia and recovery with propofol-nitrous oxide anesthesia versus thiopental sodium - isoflurane nitrous oxide anesthesia. J Clin Anesth 1991; 3: 991-4.

46 Walker GM, Foster R.S Jr, McKegney CP, McKegney FP. Breast biopsy. A comparison of outpatient and inpatient experience. Arch Surg 1978; 113: 942-6.

47 Metter SE, Kitz DS, Young ML, et al. Nausea and vomiting after outpatient laparoscopy; incidence, impact on recovery room stay and cost. Anesth Analg 1987; 66: S116.

48 Lanier WL, Warner MA. New frontiers in anesthesia research - assessing the impact of parctice patterns on outcome, health care delivery and cost. Anesthesiology 1993; 78: 1001-4.

49 Jobans TG. The cost of propofol (Letter). Anesth Analg 1995; 80: 1252-3.

50 Tarpey J, Lawler PG. Volatile agent use: perception and practice. A survey of agent use over a 3-year period. Anaesthesia 1989; 44: 596-9.

51 Kantor GS. Calculating the cost of desflurane and propofol: lower costs with lower infusion rates. Anesth Analg 1994; 79: 389-9.

52 Leaf $A$. Cost effectiveness as a criterion for medicare coverage. N Engl J Med 1989; 21 : 898-9.
53 Laupacis A, Feeney D, Detsky AS, Tugwell PX. How attractive does the new technology have to be to warrant adoption and utilization? Tentative guidelines for using clinical and economic evaluations. Can Med Assoc J 1993; 146: 473-81.

54 Naylor CD, Williams II, Basinski A, Goel V. Technology assessment and costeffectiveness analysis: misguided guidelines? Can Med Assoc J 1993; 148: 921-4.

55 Carter $A$. Background to the Guidelines for Guidelines. Can Med Assoc J 1993; 148: 3.

56 Jobnstone $R E$. Anesthesia in the ninties; practicing costeffective anesthesia. Journal 1995; 37:

57 Weiskopf $R B$, Eger El. Cost of inhaled anesthetics: In reply. Anesthesiology 1994; 80: 1407-8.

58 Braznitsky $K$. The ethics of eating a drug company donut. Can Med Assoc J 1996; 15: 154-6.

59 Wynands JE. Concluding remarks. Journal 1994; 22.

60 White PF, Watcha MF. Are new drugs cost-effective for patients undergoing ambulatory surgery? Anesthesiology 1993; 78: 2-5.

61 White PF. Impact of newer drugs and techniques on the quality of ambulatory anesthesia. J Clin Anesth 1993; 5: 3S-13.

62 Weiskopf RB, Eger El. Comparing the costs of inhaled anesthetics. Anesthesiology 1993; 79: 1413-8.

63 Fitz-James $M$. Is Pharmacoeconomics bunk? Canadian Healthcare Manager 1996; 3: 12-6.

64 Abajian JC, Viscomi CM. Cost of inhaled anesthetics: 1. Anesthesiology 1994; 80: 1404.

65 Battista $R N$. Health care technology assessment: linking science and policy-making (Editorial). Can Med Assoc 1992; 146: 461-2. 


\section{Nouveaux médicaments en anesthésie: pouvons- nous nous les payer?}

\section{Résumé}

De nos jours, le défi le plus important auquel doit faire face le médecin est la dispensation de soins de haute qualité d'une manière économiquement responsable ${ }^{1}$. Les coûts ne peuvent plus être ignorés. La pharmacoéconomie est un sujet fondamental de l'éducation médicale. Les questions économiques devraient être une composante intégrale du développement des médicaments et des essais cliniques ${ }^{2}$. Même si les anesthésistes sont préoccupés par le fait que l'utilisation de médicaments moins coûteux puisse compromettre le devenir et la satisfaction des patients ${ }^{3}$, il y a peu de données qui supportent de telles préoccupations ${ }^{4,5}$. Voilà un champ de recherches futures très fertile.

La pharmacoéconomie est une science dynamique. Le coût des médicaments n'est pas statique, les modalités d'utilisation des médicaments changent rapidement et la pratique clinique est en évolution constante. La réponse au contrôle des coûts n'est pas tout simplement de couper, de plafonner, d'exclure ou simplement d'espérer pour le mieux, mais bien de gérer et de modifier la pratique tout en accomodant des besoins changeants ${ }^{6}$.

Des programmes éducatifs, des lignes de conduite, des politiques départementales, des changements de systèmes et des motivations financières peuvent être mis en application pour assurer une adhésion solide et durable aux principes de pharmacoéconomie et de soins en tenant compte des coûts. Certains ont suggéré que les sociétés nationales devraient créer des lignes de conduite pour une pratique tenant compte des aspects coûts-bénéfices. D'autres favorisent la liberté du médecin dans le choix des médicaments ${ }^{3}$. Il est difficile de modifier le comportement du médecin. Ce changement va se faire graduellement et sera le sujet de plusieurs débats philosophiques émotivement très chargés. Il y aura beaucoup de réticence à priver les patients de médicaments supérieurs au point de vue pharmacologique seulement à cause de leurs coûts, surtout que les médicaments ne représentent qu'une très faible partie des coûts totaux ${ }^{7}$. Nous devons faire attention pour ne pas consacrer notre énergie à des économies de bout de chandelle. Les coûts d'achats des médicaments ne sont qu'un élément d'une équation vaste et complexe. Se concentrer sur les coûts d'acquisition des médicaments peut être dangereux, naïf même. si nous succombons au paradoxe de connaitre le prix de tout mais la valeur de rien du tout.

\section{La réalité économique}

Le statu quo est tout simplement non défendable. La crise de budgétisation dans les soins de santé a créé le besoin de réformer, de restructurer, de réorganiser et de diminuer tout le système. Au début, les coûts étaient diminués en fermant des lits, maintenant ce sont des hôpitaux entiers qui ferment. Ces changements ont une importance révolutionnaire et se produisent à une allure frénétique. Dans les prochaines décades, le stress sur le système va augmenter à cause de la démographie. La proportion de gens âgés va atteindre des sommets record et la demande de soins de santé va monter en flèche.

La prolifération des nouveaux médicaments coûteux dans cet environnement fiscal requiert que des efforts soient faits pour diminuer les façons de prescrire dispendieuses et inappropriées. Le luxe de pouvoir prendre des décisions cliniques tout en ignorant les coûts est un paradis perdu ${ }^{9,10}$. Ce n'est plus adéquat d'établir qu'une nouvelle médication est sécuritaire et efficace. Nous devons aussi déterminer l'impact économique d'un nouveau médicament pour en établir les coûts, les bénéfices et la disponibilité. On demandera aux médecins de participer, de coopérer, de faire des compromis. Les choix cliniques doivent être justifiés tout en essayant de diminuer les coûts et d'augmenter la qualité.

\section{Connaissances des coûts}

La connaissance du coût des médicaments est un fondement essentiel dans la discussion de la pharmacoéconomic. Cette connaissance du coût du médicament est aussi importante que la connaissance de son comportement pharmacocinétique et pharmacodynamique. Le coût peut être beaucoup plus important que la légère réponse circulatoire. Il est perturbant de constater que les médecins autant que les patients ont peu de notions concernant le coût des médicaments ainsi que ceux des soins de santé en général ${ }^{4,12}$. Des études ont montré que, même si $92 \%$ des anesthésistes recon- 
naissent l'importance du coût, seulement $42 \%$ connaissent le coût des médicaments qu'ils utilisent quotidiennement. Moins de $1 \%$ des articles publiés présentent des données sur les coûts ${ }^{1}$. La plupart des anesthésistes, soit $84 \%$, croient qu'ils n'ont pas reçu suffisamment de formation concernant les coûts, et $53 \%$ croient qu'encore de nos jours les résidents ne reçoivent pas une éducation adéquate sur le sujet ${ }^{3}$.

Le fait d'afficher le coût des médicaments et de tenir des séminaires éducatifs sur le sujet peut réduire l'utilisation de médicaments coûteux ${ }^{4,5,13}$. Dans une autre étude, l'utilisation d'étiquettes affichant les prix $n$ 'a eu aucun effet sur l'utilisation des médicaments ${ }^{14}$. Même si l'éducation seule peut entrainer des diminutions temporaires des dépenses liées aux médicaments, il faudra probablement des changements de système, des motivations, des lignes de conduite, des rationnements pour que les modes de pratique des médecins changent et qu'on contrôle les coûts $3,4,15-17$

\section{Coûts d'acquisition des médicaments}

De tous les coûts reliés à l'anesthésie, c'est celui des médicaments qui s'accrôit le plus rapidement ${ }^{4}$. En 1991, la dépense mondiale totale annuelle en agents d'inhalation disponibles à cette époque était de 450 millions, sans compter le $\mathrm{N}_{2} \mathrm{O}$. Depuis ce moment, des agents nouveaux plus coûteux, les desflurane et le sevoflurane, se sont ajoutés. En général, les nouveaux médicaments sont plus coûteux que les anciens. La différence est parfois considérable, de plusieurs ordres de grandeur. L'halothane coûte 3\% du prix du desflurane.

Les prix des médicaments ne sont ni statiques ni universels. Les prix varient selon les pays ${ }^{20}$, et peuvent même varier d'un hôpital à l'autre dans une même ville. Les coûts varient en relation avec des escomptes liés ạu volume acheté ${ }^{21}$, et cette pratique devient populaire auprès de regroupements d'acheteurs qui contractent auprès de groupes d'hôpitaux. Le coût de médicaments individuels peut devenir difficile à calculer si leur prix est dépendant de regroupements d'achats avec d'autres fournitures et équipements.

Même si de petites augmentations de coûts ont peu de répercussions sur les coûts pour un patient individuel, ces dépenses multipliées par les millions de procédures chirurgicales réalisées annuellement représentent un coût renversant $t^{9,18}$. Le fait de remplacer le thiopental par le propofol représente une dépense supplémentaire de $\$ 7.00$ par patient. En estimant le nombre de chirurgie à 25,000,000 par an aux États-Unis, si 4\% des patients reçoivent du propofol au lieu du thiopental, la dépense supplémentaire est de $\$ 7,000,000$. Si $50 \%$ des patients reçoivent du propofol, la facture devient $\$ 87,500,000$. À la fin de la journée, il faut évaluer si le bénéfice justifie le coût. Un système financé à même les deniers publics doit répartir les ressources pour le bien de la majorité et doit être convaincu que les dépenses supplémentaires vont avoir un impact positif et palpable. Les coûts additionnels doivent être défrayés par des augmentations de taxes, ou par des transferts de fonds d'autres programmes ou en réalisant un déficit.

Cependant, le coût des médicaments doit être considéré dans sa perspective, ceux-ci représentant une très petite partie des coûts totaux. Les médicaments représentent un tiers des coûts non professionnels de l'anesthésie. Les agents anesthésiques représentent de 4 à $25 \%$ des coûts totaux des médicaments d'un hôpital, $6 \%$ des coûts des salles d'opération et $1 \%$ des coûts totaux d'un hôpi$\operatorname{tal}^{33,4,22,23}$. Les coûts de la main d'oeuvre sont d'un autre ordre de grandeur, grossièrement 50 fois ceux des médicaments. Alors que les coûts en médicaments pour une procédure ambulatoire d'une durée de 1 heure varient de $\$ 11.05$ pour l'isoflurane à $\$ 20.00$ pour le propofol, les coûts en personnel de la salle d'opération sont d'environ $\$ 680.00$ et ceux de la salle de réveil de $\$ 328.00^{24}$. Le coût du propofol pour une procédure neurochirurgicale prolongée représente à peu près la moitié du prix d'une pince sugita ${ }^{25}$ et représente un très petit pourcentage du coût global des soins qui se situe à environ $\$ 25,000^{26}$. Le coût des médicaments anesthésiques est minime comparé à l'utilisation d'agrafes pour la fermeture des plaies ${ }^{27}$. Dans la chirurgie de la cataracte, le coût des médicaments anesthésiques perd toute importance face au coût du médicament Healonid et des implants ${ }^{28}$.

\section{Coût $p s$ qualité}

$\grave{A}$ un bout du spectre, certains croient que les coûts des médicaments sont sans importance et que les agents anesthésiques sont bon marché, même à deux fois le prix ${ }^{29}$. En dépit du sentiment que le coût est important, la majorité des anesthésistes est d'accord avec le fait que le meilleur médicament doit être utilisé indépendamment du coût $t^{4,22,27,28,30,31}$. Même les adeptes de la recherche sur les coûts-bénéfices servent la mise en garde que la première préoccupation doit être le bien-être du patient ${ }^{32}$.

À l'autre bout du spectre, d'autres croient qu'un coût faible prime sur une qualité élevée. Même des soins de santé médiocres sont préférables à pas de soins du tout. Même s'il y a beaucoup de réticence à faire des compromis sur la qualité des soins en faveur des économies, il n'est plus possible d'ignorer le problème ${ }^{7}$. On presse les anesthésistes d'examiner les conséquences économiques des décisions prises en pratique quotidienne, et de se demander «Pourquoi est-ce que j'utilise cette médication? Existe-t-il une 
option moins coûteuse? ${ }^{33} \mathrm{La}$ solution de mandater des médecins pour suivre l'utilisation des médicaments dispendieux a aussi été suggérée'. L'ère de l'autonomie du médecin est révolue: les administrateurs d'hôpitaux exigent des médecins une conscience des coûts. D'autres coupures vont non seulement accroître la pression pour favoriser le coût-efficacité et le contrôle des coûts mais aussi la réduction de coût et la minimalisation des coûts. La majorité des anesthésistes est d'accord que des médicaments moins coûteux peuvent être utilisés plus souvent sans diminuer la qualité des soins ${ }^{3}$. Pour ceux qui ont peu de motivation altruiste, le budget global pour les fournitures, l'équipement, les frais fixes et les dispensateurs de soins a entraîné une convergence des intérêts des médecins et des hôpitaux. On a aussi proposé de partager les économies réalisées sur les coûts comme incitatifs financiers ${ }^{34}$.

\section{Les soins basés sur la valeur}

De façon historique, le marché des soins de santé n'a pas été régi par l'équilibre conventionnel de l'offre et de la demande et du rapport coût-qualité. Pour les soins de santé, la demande est devenue insensible aux prix, choisissant la meilleure qualité sans égard aux coûts $^{34-37}$. La relation entre les coûts et les résultats est complexe mais, en général, les relations coûts-bénéfices ont une pente ascendante dont la pente diminue pour éventuellement atteindre un plateau. Par la suite, l'ajout de ressources supplémentaires ne produit que peu ou pas d'amélioration ${ }^{34-38}$. Des choix de médicaments coûteux doivent être justifiés par des améliorations significatives et non marginales des soins au patient. Les agents anesthésiques utilisés de nos jours ont un dossier établi de sécurité et d'efficacité. Le défi des nouveaux agents anesthésiques coûteux est de démontrer une amélioration dramatique par rapport aux excellents médicaments déjà dans notre arsenal anesthésique. Le conflit entre le coût et la qualité a forcé la recherche des soins basés sur la valeur, qui définit la relation entre les coûts d'une stratégie de traitement anesthésique et la valeur de ces soins tel que reflété par le devenir du patient, la satisfaction du consommateur et l'efficacité du programme ${ }^{33}$.

Le temps, c'est de l'argent. La valeur du temps en salle d'opération est estimée entre $\$ 2$ et 6.00 de la minute, jusqu'à un maximum de $\$ 11.34^{24}$. La demande d'une efficacité accrue et de résultats de qualité a généré de l'intérêt pour les nouveaux médicaments présentant un début d'action rapide et une courte durée d'action. L'efficacité de la salle d'opération peut être accrue en utilisant de nouveaux médicaments à courte durée d'action $^{15}$. Pour évaluer les bénéfices cliniques de ces nou- veaux médicaments plus rapides, les études ont comparé les temps requis pour l'ouverture des yeux, pour l'obéissance aux ordres, pour l'extubation ainsi que les temps de roulement ${ }^{40}$. L'efficience est multifactorielle et les médicaments ne sont pas toujours les agents limitants ${ }^{33,41}$. Les délais peuvent être causés par le nursing, l'entretien ménager, les médecins ${ }^{42}$, et par des problèmes liés à l'équipement qui ne peuvent être améliorés par des médicaments plus rapides.

La valeur du temps en salle de réveil est évaluée approximativement à $\$ 1.00$ la minute $^{7}$ ou $\$ 103.00 \mathrm{par}$ patient $\mathrm{t}^{22}$ et autant que $\$ 330.00$ par patient aux ÉtatsUnis $^{24}$. Les nouveaux médicaments pourraient réduire les coûts de salle de réveil en réduisant la durée de séjour ou en permettant aux patients d'éviter complètement la salle de réveil. Les salaires et avantages des infirmières représentent $47 \%$ des coûts d'un centre de chirurgie ambulatoire ${ }^{43}$. Les besoins en personnel ont été déterminés longtemps avant que le patient arrive à la salle de réveil. Des modèles informatisés ont documenté les économies théoriques en salle de réveil dues au séjour plus court et aux besoins nursing réduits des patients ${ }^{4-46}$. Les économies calculées sont basées sur la proposition que les soins nursing sont défrayés sur une base de paiement à l'acte ${ }^{43-47}$. Les vraies économies ne sont générées que lorsqu'il y a moins d'infirmières assignées d'avance comme personnel de la salle de réveil, et ce sur une base régulière. Dans le contexte actuel cela signifie des pertes d'emplois, des mises à pied et du chômage.

\section{Les revues d'utilisation}

Les conflits surviennent lorsque ceux qui paient pour les médicaments refusent ou sont incapables de payer. Pour des raisons financières, des hôpitaux peuvent être forcés à défendre ou à cesser certains médicaments, limitant les formulaires hospitaliers au strict minimum ${ }^{1,48,49}$. Le but final des revues d'utilisation est le rationnement. Le rationnement est déjà une réalité dans quelques hôpitaux et il deviendra plus fréquent ${ }^{5,23,33,50}$. Des institutions ont économisé plus de $\$ 400,000$ par année en restreignant l'utilisation des relaxants musculaires, des opiacés et des agents d'inhalation ${ }^{5,23,33,50}$. La majeure partie des économies a été réalisée en substituant des médicaments plus anciens, moins coûteux, disponibles sous forme générique comme le pancuronium, l'halothane, la morphine ou le fentanyl. Une éducation et un renforcement continus sont nécessaires pour maintenir ces changements ${ }^{5}$. Plusieurs croient que les résultats ne sont pas touchés par l'utilisation de médicaments moins chers ${ }^{33,51}$ et les études n'ont pas montré que les résultats périopératoires étaient affectés ${ }^{4}$. Le processus de revue d'utilisation doit permettre d'économiser un montant substantiel car ce montant doit aussi défrayer le 
coût du processus lui-même. Ces revues nécessitent du personnel administratif supplémentaire et certains sont inquiets de savoir si ceux qui gèrent les coûts ne coûtent pas plus que ce qu'ils permettent d'économiser.

\section{Lignes de conduite}

L'élément coût-efficacité deviendra peut-être un critère d'acceptation de nouveaux médicaments ${ }^{52}$. Ceci est quelque peu perturbant puisque les lignes de conduite dans le domaine coût-efficacité sont controversées et arbitraires $^{53,54}$. Toute la question entourant l'utilisation de lignes de conduite est si complexe qu'on a dû créer des lignes de conduite définissant comment établir des lignes de conduite ${ }^{55}$. Laupacis a étudié le conflit entre le coût et la qualité et il définit quatre relations possibles ${ }^{53}$. D'abord le scénario où un médicament est meilleur et moins cher, et où il est accepté d'emblée de tous. Ensuite, le scénario où un médicament est plus cher tout en étant associé à des résultats moins bons ce qui entraîne un rejet par tous. Troisièmement, le scénario controversé mais fréquent où le médicament est meilleur mais plus cher. Des lignes de conduite arbitraires pour l'acceptation du produit sont mises de l'avant (avec la présomption qu'il existe plus d'argent à quelque part pour assumer les coûts supplémentaires). Le quatrième scénario, aussi controversé et fréquent, est celui d'un médicament moins cher mais entraînant des résultats inférieurs. Laupacis suggère que, si les économies réalisées sont considérables, l'échange entre coût et qualité peut être justifié ${ }^{53}$. L'halothane est un bon exemple de cette controverse. Certains anesthésistes utilisent l'halothane comme médicament de premier choix parce qu'il est moins cher ${ }^{56}$. D'autre part, d'autres anesthésistes n'utilisent jamais l'halothane ${ }^{51}$, croyant que l'halothane ne représente plus qu'un intérêt historique, compte tenu du risque d'hépatite et du climat médico-légal actuel ${ }^{57}$.

\section{L'industrie pharmaceutique}

On se préoccupe de ce que la production et la mise en marché de nouveaux agents soient beaucoup plus importantes pour les manufacturiers que pour notre profession ou nos patients ${ }^{31}$. Un nouveau relaxant musculaire ou un nouvel agent d'inhalation peut apporter un bénéfice minime du patient mais générer des millions en profits pour la compagnie. L'industrie pharmaceutique est la source la plus fréquente de renseignements concernant le coût d'un médicament ${ }^{51}$. Les barrières à un choix objectif d'un médicament incluent, non seulement la grande quantité d'informations et les cédules de travail trépidantes, mais aussi la tentation de s'en remettre aux sources commerciales pour l'éducation médicale continu $^{37}$. L'influence de la compagnie pharmaceutique faisant de la mise en marché, le «dîner gratuit » et la promotion du médicament par le biais de cadeaux sont tous des sujets fort préoccupants ${ }^{4}$. Certains ont avancé qu'un « dîner gratuit» ça n'existe pas et que nous devrions nous étouffer avec chaque particule de beigne souillé offert par une compagnie pharmaceutique ${ }^{58}$. L'Association Médicale Canadienne a répondu à certaines de ces questions en établissant des lignes de conduite qui gouvernent les relations entre les médecins et les compagnies pharmaceutiques.

D'autres croient que nous faisons plus qu'acheter des médicaments et ils voient les relations avec l'industrie pharmaceutique comme symbiotiques et de support mutuel. Au cours des ans, de nouveaux médicaments mis au point par l'industrie ont révolutionné la pratique de la médecine. L'industrie pharmaceutique commandite une partie substantielle de l'éducation médicale continue, contribue aux congrès, aux récompenses des travaux de recherche, aux bourses de recherche, défraie les essais cliniques et, par les annonces commerciales, subventionne les journaux de recherche. Nous allons continuer à avoir besoin de l'industrie pharmaceutique pour développer de nouveaux médicaments pour rencontrer les défis actuels et pour financer nos efforts de recherche en médecine clinique et en pharmacoéconomie ${ }^{59}$.

\section{Études de pharmacoéconomie}

Pour que des nouveaux médicaments puissent remplacer des médicaments existants, ce n'est plus suffisant de simplement démontrer la sécurité et l'efficacité dans des essais aléatoires, à double insu et contrôlés par placebo; dans l'environnement actuel des soins de santé, ils doivent rencontrer des normes plus élevées ${ }^{60,61}$. Un nouveau médicament doit offrir un bénéfice thérapeutique accru, le tout à un coût abordable ${ }^{62}$. Ceci a créé un besoin pour des études de pharmacoéconomie.

On retrouve tout l'éventail des opinions concernant la pharmacoéconomie. À une extrémité du spectre, on retrouve la croyance que la "pharmacoéconomie est une oubliette!n. ${ }^{4}$ À l'autre extrémité, on croit que les études de pharmacoéconomie sont la base de décisions politiques d'envergure, de lignes de conduite cliniques, d'inscription aux formulaires et de remboursement par les assurances.

Si un consommateur désire de l'information concernant une nouvelle voiture, un ordinateur ou un appareil de télévision, il existe une variété de documents et de revues pour renseigner ce dernier. Ces évaluations sont faites uniquement au profit de l'acheteur; elles sont compilées de façon isolée du manufacturier et sont défrayées par le consommateur et non le manufacturier. Ces publications n'acceptent pas la publicité et si leurs 
résultats sont utilisés par les manufacturiers pour des motifs de mise en marché, ces derniers peuvent être poursuivis. Au contraire, les compagnies pharmaceutiques jouent un rôle clé dans le développement et la production d'analyses économiques utilisées pour annoncer leurs produits et pour diriger des décisions d'inclusion aux formulaires. Il existe des mises en garde que des décisions de politique ne devraient pas être basées sur des études économiques fournies par des compagnies pharmaceutiques qui ont dépensé des millions en recherche et développement et ont des intérêts immenses dans les résultats des études. Il peut être difficile d'évaluer si vous êtes renseignés par des experts ou manipulés par des vendeurs ${ }^{63}$.

La pharmacoéconomie n'est pas une science rigoureuse et a été dénoncée comme une "pseudoscience». La pharmacoéconomie est "plastique» parce que son point de vue change constamment ce qui rend les conclusions malléables, dépendant de la perspective de l'analyse. Des partis pris dans l'évaluation de la technologie sont un problème majeur mais inévitable puisque la validité économique d'une nouvelle technologie doit être évaluée à partir d'une certaine perspective. Les médecins sont sceptiques et fatigués d'être manipulés ou désinformés par les compagnies pharmaceutiques ou leurs représentants ${ }^{64}$. Par exemple, la meilleure évaluation des coûts du desflurane a été rapportée par des chercheurs ayant un intérêt financier dans cet agent ${ }^{64}$. On a prétendu qu'utilisé à flots réduits le desflurane est réellement moins cher que l'isoflurane, les budgets des médicaments anesthésiques devraient donc diminuer à mesure que l'usage du desflurane s'accroît ${ }^{19}$.

$\mathrm{Au}$ contraire, d'autres croient que les compagnies pharmaceutiques devraient jouer un rôle fondamental dans les études de pharmacoéconomie. Elles sont propriétaires des médicaments et possèdent le plus d'informations à leur sujet. Probablement, la raison principale d'inclure les compagnies est qu'elles ont les ressources financières pour financer ces recherches, spécialement de nos jours où les dollars pour la recherche sont rares. Comme les défauts dans le protocole expérimental vont éventuellement apparaître durant le processus d'évaluation et comme ils vont influencer de façon négative la crédibilité de la compagnie, c'est le meilleur intérêt de la compagnie de s'assurer que la recherche est conduite de façon rigoureuse. Plusieurs compagnies demeurent à distance des études qu'elles commanditent précisément de façon à demeurer plus crédibles lorsque leurs produits doivent être achetés par les gens responsables des formulaires. Dans.certaines études, les compagnies pharmaceutiques abandonnent le contrôle quant à l'élaboration, la conduite, l'analyse, l'interprétation, le rapport et la publication. Leur seule participation est la signature du chèque $^{63}$. Certains suggèrent que des études au moment de leur planification devraient être revues par un conseil d'évaluation des technologies de santé pour assurer une méthodologie solide et une conformité à des lignes de conduite établies et cohérentes et pour réduire les biais. Cette façon de procéder assurerait à l'étude son sceau d'approbation «Good Housekeeping» et améliorerait la crédibilité. L'évaluation économique doit être considérée comme une technologie prometteuse, clairement utile, mais nécessitant encore du raffinement et, comme toute nouvelle technologie, sujette à une utilisation rationnelle ou des abus accidentels ${ }^{54}$. La pression va se faire de plus en plus forte pour lier science et définition de politiques comme des parties fondamentales de la pratique d'une médecine basée sur des évidences ${ }^{65}$. L'analyse coût-bénéfice aide le processus de définition de politiques, mais la prudence s'impose quant aux limitations de ce paradigme.

\section{Conclusion}

Contrôle des coûts et amélioration continue de la qualité: peuvent-ils coexister? Les nouveaux médicaments peuvent améliorer la qualité, mais ils augmentent aussi les coûts. Ceci crée des tensions entre l'amélioration de la qualité et le contrôle des coûts. Alors que les médicaments ont joué un rôle fondamental dans la formation du système de soins de santé, la recherche doit maintenant se vouer à l'identification et à l'évaluation d'une utilisation judicieuse et abordable de ces nouveaux médicaments. Des jugements de valeur sont fondamentaux dans le processus de prise de décision clinique ${ }^{10}$. Les questions sont de nature économiques et éthiques. Bien que les coûts ne doivent pas être le facteur dominant, on va nous demander d'utiliser la stratégie la moins coûteuse pour l'obtention d'un résultat acceptable. Le dilemme réside dans la définition de «acceptable». Combien bon est suffisamment bon? Malheureusement, compte tenu de nos budgets qui rétrécissent, il est inévitable que certaines nouvelles technologies seront tout simplement hors de prix.

\section{Références}

(Voir page R99) 